the second and third thoracic ganglion, showed no change. Only in the first thoracic ganglion, which lies in the immediate vicinity of the puncture, did glia cells and the neuropilem manifest alterations. Although the nuclei of the glia cells were present and the cell boundaries discernible. The plasma region of these cells appeared empty and the neuropilem did not evince its usual fibrous ground structure. The ganglion cells, however, remained unchanged. Only $24 \mathrm{~h}$ after stinging do the changes of the neuropilem and the glia cells spread to the other thoracic ganglions, but nerve cells and the cells of the perineurium are almost never affected. Not until three days after the stinging is shrinkage in the brain and the subœsophageal ganglion noticeable.

It is possible that after peripheral paralysis has set in, the poison disturbs the metabolic functions of the glia cells which are responsible for the nutrition of the neurones. The lack of essential nutrients could be the cause for the viscous degeneration of the neuropilem. The histological examinations have shown that the poison does not attack primarily ganglion centres, for those ganglions at some distance from the puncture, for example, the second and third thoracic ganglion, exhibit degeneration only after a day. The respective extremities, however, are immovable within a few seconds.

The potent effect of Philanthus poison is not confined only to the honey-bee. On the contrary, positive results were obtained with all insect orders, spiders and even closely related Sphecidae. Just as remarkable is the fact that Philanthus is immune to its own poison, toxicity being destroyed by a particular compound in its hæmolymph. Only in very strong concentrations can the poison cause a momentary paralysis in the musculature. Within a very short time the local paralysis is checked by the hæmolymph. If the poison is injected directly into a thoracic ganglion of a Philanthus, the legs will become paralysed. Whether in this instance the structure of the ganglion is damaged or a nerve-nerve synapsis is blocked has not as yet been determined. Since insect ganglia are not bathed by hæmolymph, the poison in this case cannot be rendered ineffectual.

Philanthus can be killed by its victim's poison if the bee successfully introduces its sting into the heavily sclerotized body of the wasp. This is, of course, an exceptional case. There is a Mediterranean species of digger wasp, Palarus variegatus, F, which preys among other aculeate hymenoptera on Philanthus. The apparent immunity of this species to the poison of the latter has obvious selective advantage. Whereas the victim's poison may be fatal to Philanthus, in this case, the hunter is immune to the poison of its prey.

The illustrations used in this article are from $Z$. vergl. Physiol., 45, 413; 1962 (Springer-Verlag: Berlin, Göttingen, Heidelberg).

${ }^{1}$ Nielsen, E. T., Vidensk. Medd. naturk. Foren., 99, 149 (1932).

${ }^{2}$ Hartzell, A., Contr. Boyce Thomson Inst., 7,421 (1935).

s Rathmayer, W., Z, vergl, Physiol, 45, 413 (1962).

4 Krijgsman, B. J., Biol. Rev., 27, 320 (1952).

\title{
OBITUARIES
}

\section{Sir Irvine Masson, M.B.E., F.R.S.}

Sir Irvine Masson, M.B.E., formerly vice-chancellor of the University of Sheffield, died in Edinburgh on October 22, 1962, at the age of seventy-five. He was a grandson of David Masson, professor of English literature at University College, London, from 1853 until 1865, and at the University of Edinburgh from 1865 until 1895, and the only son of Sir David Orme Masson, professor of chemistry at the University of Melbourne during 1886-1923.

James Irvine Orme Masson was born on September 3, 1887, in Melbourne, where he was educated at the Grammar School and the University before coming to Great Britain in 1910 as an 1851 Exhibition Scholar. After a year with Sir James Walker at Edinburgh, Masson moved to University College, London, where he worked with Sir William Ramsay, with whom his father had been associated some thirty years earlier at University College, Bristol. In 1912 Masson became assistant in chemistry at University College, London, and during the First World War he served first with the R.N.V.R. and later at the Research Department of the Royal Arsenal, Woolwich. $\mathrm{He}$ was appointed reader in inorganic chemistry at University College in 1920, and served as secretary of the Chemical Society during 1921-24. He became the first professor of chemistry and head of the Department of Pure Science of the University of Durham (Durham Division) in 1924, and in 1938 he went as vicechancellor of Sheffield, where he remained until retirement in 1952. At the outbreak of the Second World War he added to his duties as vice-chancellor the active direction of a Ministry of Supply team which was housed in the Chemistry Department and engaged in research on explosives. He was also a member and chairman of several committees of the Ministry.

Irvine Masson was a man of varied talents. His chemical work, which led to election to the Royal Society in 1939, was not voluminous, since he never had a large team of helpers and much was done with his own hands. But his work is characterized by elegance and breadth; problems were reduced to the simplest possible terms and then approached by neat, ingenious and well-considered methods. He belonged to the group of chemists-now non-existent-who could tackle equally well problems in the inorganic, physical and organic sections of chemistry. His early publications were concerned with the theory of solution and the gas laws, and his use of the inert gases was clearly an outcome of association with Ramsay, for whom he had unbounded admiration. But his most significant contributions were his studies of nitration and of the organic compounds of iodine. The nitration work is a classic, paving the way for later researches which have had an important bearing on the development of theoretical organic chemistry. The study of organic iodine compounds had been neglected since the work of Victor Meyer and Willgerodt some forty years earlier; Masson developed this work in an important series of researches, in which he demonstrated once more his remarkable ability to apply physical chemistry to problems in both organic and inorganic fields.

Masson was interested in the teaching of science, frequently serving as external examiner at other 
universities, and his book, Three Centuries of Chemistry, published in 1925, shows a profound knowledge of the historical and philosophical aspects of his subject. While science was his profession, classics and the arts were hobbies in which he reached professional standing. He was a groat lover of books and an expert in the early history of printing. His major contribution in this field-the fruit of research during the latter years of his vice-chancollorship-is an outstanding monograph on the Mainz Psalters and Canon Missae.

Masson was tireless in his efforts on behalf of the University of Sheffield, and his flair for the lucid presentation of complex matters of finance and statistics proved invaluable. No one knew better than he what education was or what a university should and could do. As vice-chancellor he steered the University through its war-time problems and through the equally difficult period of development which followed. He made plans to guide the expansion from 850 students to a well-balanced and effective University of some 2,500 students (a target now increased to 4,750); temporary structural alterations were made and building programmes initiated; Stephenson Hall and the new Chemistry and Engineering Departments wero almost completed before his retirement in 1952 .

Though invariably courteous and dignified, Masson was nevertheless a determined fighter, often outspoken in formal debate. In contrast, his natural shyness in personal relationships was a handicap frequontly mistaken for aloofness. Rarely at his best in large gatherings, ho was an excellent host of a small party, with a turn of wit which would have surprised his detractors. Those who knew him well found him a lively companion and a true friend.

Masson became M.B.F. in 1918, was knighted in 1950, and received the honorary degree of LL.D. of the Universities of Edinburgh and Sheffield. His retirement, spent in bibliographical work in Edin- burgh and in advisory posts to the Carnegie Trust and the University of St. Andrews, was saddened by the long illness of his wife Flora Lovell, daughter of Prof. G. Lovell Gulland, whom he married in 1913 and who died in 1960. He leaves one son, who is sub-librarian in charge of the Brotherton Collection at the University of Leeds.

\section{R. D. Haworth}

A. H. Lambertom

\section{Prof, Kh. M. Abdullaev}

THE death of Khabib Mukhamedovich Abdullaev, president of the Academy of Sciences of Uzbekistan and former vice-premier of the Uzbek Council of Ministers, has been reported from Tashkent. Prof. Abdullaev visited Britain in 1960 and lectured on the geology and mineral resources of the Central Asian republics at several British universitios. Although only fifty years old, he was the author of many geological monographs on the ore deposits of Central Asia, among them his doctoral dissertation on the scheelite deposits in the mountains of Uzbekistan and a number of lengthy works on the genetic connexion between mineralization and igneous intrusions. His book on Dykes and Mineralization (1957) brought him a Lenin prizo; an English translation has just been published by the American Geological Institute.

Apart from his activitios as an oconomic goologist, Abdullaev took a prominent part in the post-war organization of scientific affairs in Central Asia, in recognition of which he was awarded many Russian decorations. He spoke only Uzbek and Russian; but as a representative (and corresponding member) of the U.S.S.R. Academy of Sciences he latterly travelled widely on scientifio missions to Western Europe, Mexico, China and India. He was a member of the Mineralogical Society of Great Britain.

\section{NEWS and VIEWS}

\section{Biochemistry at Adelaide}

SIR MArk Mitchele, who has held the appointment of deputy vice-chancellor in the University of Adelaide since 1948, has resigned his chair of biochemistry in order to devote the whole of his time to the office of deputy viee-chancellor. Prof. R. K. Morton, Waite professor of agricultural chemistry in the University of Adelaide, has been appointed professor of biochemistry. Prof. Morton is a Fellow of the Australian Academy of Scionce. He recently returnod to Adelaide after spending several months in England as a visiting Fellow under the auspices of the Commonwealth Fellowship and Scholarship Plan. Morton is distinguished for his work on purifiod enzymes and cytochromes including tho first example of a protein containing two coloured prosthetio groups both necossary for enzyme activity. His method of purifying enzymes was a valuable contribution. He has also done important work on nucleic acids and plunt proteins. During the Second World War ho servod in the Royal Navy and from 1949 until 1952 worked at Cambridge in tho laboratories of Dr. Maloolm Dixon.

\section{Demand for Graduates in Agriculture in Britain}

IN a written answer in the House of Commons on November 27, the Minister of Agriculture, Fisheries and Food, Mr. C. Soames, announced that, with the Home Secretary and the Secrotary of State for Scotland, ho had docided to set up a committee of inquiry to assess the present and future demand, at home and abroad, by agriculture (including horticulture), its associatod industries and public services, for graduates from agriculture and othor facultics or departments of universities in the United Kingdom. The chairman of this committee would be Dr. C. I. C. Bosanquet and its members would bo: Sir Arthur Benson, Mr. A. S. Cray, Mr. J. L. Davies, Mr. R. A. Hamilton, Prof. D. S. Hendrie, Dr. W. G. Humphrey, Prof. H. G. Lamont and Mr. Maitland Mackie.

\section{The International Association for the Exchange of Students for Technical Experience :}

Annual Report

Tre fifteenth annual report of the International Association for the Exchange of Students for Technical Experience covering the year 1962 has recently been issued (Pp. 88. Bad Godesborg: Dr. Klaus Wyneken, General Secretary, IAESTE, Frankengraben 50, 1962). The report records an increase of 185 over 1961 in students exchanged, 60 of whom were sent abroad by the new member country, Treland, the remaining increase ovor 1961 being mainly from five countries. Tho main part of the exchange is still 